\title{
SIKAP, KEYAKINAN, NIAT DAN PERILAKU MASYARAKAT BINAAN KADER WARGA PEDULI AIDS (WPA) TERHADAP PENANGGULANGAN HIV DAN AIDS DI KOTA KUPANG
}

\author{
Imelda Februati Ester Manurung1, ${ }^{*}$, Rini Maulesu'2, Pius Weraman ${ }^{3}$, Andreas Umbu Roga ${ }^{4}$ \\ 1,2,3,4 Ilmu Kesehatan Masyarakat, FKM, Universitas Nusa Cendana, Indonesia \\ Email: 1imelda.manurung@staf.undana.ac.id \\ Email: 2nataliarheenee@yahoo.co.id \\ Email: 3piusweraman@yahoo.com \\ Email: ${ }^{4}$ anderias_umburoga@staf.undana.ac.id
}

\begin{abstract}
ABSTRAK
Tren sebaran kasus baru HIV menunjukkan terjadi peningkatan pada kelompok ibu rumah tangga. Fakta ini menunjukkan bahwa HIV dan AIDS sudah menjadi masalah di masyarakat dan rumah tangga. Warga peduli AIDS (WPA) adalah salah satu kegiatan untuk penganggulangan HIV dan AIDS di tingkat kelurahan yang mendampingi setiap warga. Berbagai kegiatan penganggulangan HIV dan AIDS sudah dilakukan oleh masyarakat binaan kader WPA. Penelitian ini bertujuan untuk mengetahui bagaimana gambaran sikap, keyakinan, niat dan perilaku masyarakat warga binaan kader WPA terhadap penanggulagan HIV dan AIDS. Jenis penelitian adalah deskriptif kuantitatif. Populasi penelitian adalah seluruh warga yang pernah memperoleh pembinaan dari kader WPA. Jumlah sampel penelitian sebanyak 102 orang. Teknik pengambilan sampel menggunakan random sampling. Instrumen penelitian menggunakan kuesioner. Data dianalisis secara deskriptif. Hasil peneltian menunjukkan bahwa sebagian besar nilai variabel responden berada dalam kategori baik yaitu pengetahuan sebanyak 72 (70,6\%), Sikap 59 (57,8\%), keyakinan 58 (56,9\%), niat 56 (54,9\%). Namun untuk variabel perilaku lebih banyak pada kategori buruk yaitu sebanyak 56 (54,9\%) responden. Sebagian besar responden memiliki sikap, keyakinan dan niat dalam kategori baik, namun bila dibandingkan dengan responden yang bernilai buruk, perbedaannya tidak jauh. Oleh karena itu perlu pendampingan yang lebih intensif untuk meningkatkan sikap, keyakinan dan niat warga. Selain itu bimbingan terhadap warga yang masih takut melakukan tes HIV.
\end{abstract}

Kata kunci: sikap, keyakinan, niat, perilaku, warga peduli AIDS

\section{ABSTRACT}

Trends in the distribution of new cases of HIV show an increase in the group of housewives. This fact shows that HIV and AIDS has become a problem in society and households. Citizens concerned about AIDS (WPA) is one of the activities to tackle HIV and AIDS at the village level that accompanies every citizen. Various HIV and AIDS prevention activities have been carried out by the community trained by WPA cadres. This study aims to find out how the attitudes, beliefs, intentions and behavior of the 
IAKMI Jurnal Kesehatan Masyarakat Indonesia, Volume 1, No. 1, April 2020

Journal Homepage : http://jurnal.iakmi.id/index.php/IJKMI

ISSN 2721-9437 (Media Online)

community members fostered by WPA cadres towards HIV and AIDS prevention. This type of research is quantitative descriptive. The study population was all residents who had received guidance from WPA cadres. The number of research samples were 102 people. The sampling technique uses random sampling. The research instrument used a questionnaire. Data were analyzed descriptively. The results of the study indicate that most of the respondents' values are in the good category of knowledge as much as 72 (70.6\%), Attitudes 59 (57.8\%), confidence 58 (56.9\%), intention 56 (54.9\%). But for the behavioral variables more in the bad category as many as 56 (54.9\%) respondents. Most respondents have attitudes, beliefs and intentions in the good category, but when compared with respondents who have bad value, the difference is not much. Therefore more intensive assistance is needed to improve the attitudes, beliefs and intentions of citizens. In addition, guidance to residents who are still afraid to take an HIV test.

Keywords: attitudes, beliefs, intentions, behavior, people care about AIDS

\section{PENDAHULUAN}

Kasus baru orang yang terinfeksi HIV terus bertambah setiap tahunnya. Data di dunia pada tahun 2018 menunjukan bahwa kasus HIV sudah mencapai 37,9 juta dengan kasus baru mencapai 1,7 juta (UNAIDS, 2019). Kasus HIV dan AIDS di Indonesia sampai pada Bulan Desember tahun 2018 mencapai 441.347 dengan angka kasus baru sebanyak 46.659 kasus. Tren sebaran kasus HIV terjadi peningkatan pada kelompok ibu rumah tangga. Data pada tahun 2018 dan 2017 menunjukkan bahwa ibu rumah tangga menempati peringkat ke dua dari sebaran orang yang terinfeksi HIV menurut sebaran kasus berdasarkan pekerjaan (Kemenkes RI, 2019). Penularan HIV dari ibu ke anak yang ditunjukkan dengan adanya penemuan kasus HIV dan AIDS pada kelompok usia di bawah 4 tahun. Proporsi terbesar kasus HIV berada pada kelompok penduduk usia produktif (1549 tahun) mencapai 88,6\% dimana kemungkinan penularan terjadi pada usia remaja (Pusdatin, 2018).

Jumlah kasus HIV dan AIDS di Provinsi Nusa Tenggara Timur (NTT) pada tahun 2018 sebanyak 6.192 dengan Kota Kupang menempati peringkat pertama dengan jumlah kasus terbanyak HIV dan AIDS dibandingkan dengan kabupaten/kota lain. Ibu rumah tangga adalah kelompok profesi paling banyak terinfeksi HIV yaitu sebanyak 1.269 kasus (Dinkes Provinsi NTT, 2019). Kondisi ini menunjukkan bahwa kasus HIV saat ini tidak hanya berisiko pada populasi kunci seperti kelompok pekerja seks komersil, pengguna Napza jarum suntik, lelaki seks lelaki dan waria tetapi juga sudah menyebar di populasi umum yaitu rumah tangga.

Fokus penanggulangan HIV dan AIDS saat ini menitikberatkan pada pemberdayaan masyarakat. Sejak Tahun 2013 pemerintah telah mencanangkan program warga peduli AIDS (WPA). Program ini melibatkan partisipasi masyarakat yang berbasis di tingkat kelurahan/desa, rukun warga, dusun atau blok (Dermatoto, 2018). Tugas utama WPA adalah menggerakkan masyarakat untuk terlibat dalam berbagai kegiatan pencegahan dan penanggulangan HIV dan AIDS. Misi dari Kader WPA ini adalah meningkatkan pengetahuan tentang HIV dan AIDS, menghapus stigma pada ODHA, memotivasi warga untuk tes HIV secara sukarela (Wati, Cahyo, \& Indraswari, 2017). Misi dari program WPA dapat tercapai bila masyarakat sudah memiliki pengetahuan, sikap dan niat yang baik terhadap upaya penanggulagan HIV dan AIDS.

Faktor - faktor yang mempengaruhi seseorang untuk berperilaku yang benar terhadap penanggulangan HIV dan AIDS adalah pengetahuan, sikap dan dukungan 
sosial (Yuliza, Hardisman, \& Nursal, 2019). Penelitian yang dilakukan terhadap tokoh agama informal di Kota Kupang menunjukkan bahwa stigma diberikan kepada ODHA karena rendahnya pengetahuan (Manurung, UW, \& Probandari, 2016). Pengetahuan dapat mempengaruhi sikap seseorang dalam mengambil tindakan preventif terhadap HIV dan AIDS (Septyanarindri, 2011). Teori Plan Behavior menjelaskan bahwa niat seseorang untuk bertindak dipengaruhi oleh sikap dan keyakinan (Sulaeman, Murti, Setyawan, \& Rinawati, 2018). Seseorang akan melakukan upaya penanggulangan HIV jika didukung oleh sikap, keyakinan dan niat yang baik (Satar, Suryoputro, \& Shaluhiyah, 2011). Sikap positif dan keyakinan akan lebih banyak memperoleh keuntungan daripada kerugian bila tidak melakukan pencegahan HIV (Jambak, 2018). Niat merupakan prediktor untuk terwujudnya perilaku yang mendukung upaya pencegahan HIV (Arisona, Demartoto, \& Murti, 2017).

Komisi Penanggulangan AIDS Kota Kupang memulai program WPA mulai tahun 2013. Sejak program WPA diimplementasikan belum pernah dilakukan evaluasi terhadap perubahan sikap, keyakinan, niat dan perilaku masyarakat binaan kader WPA terhadap penanggulangan HIV. Kota Kupang merupakan kabupaten/kota pertama di Provinsi NTT yang melakukan pemberdayaan kader WPA untuk melakukan penanggulangan HIV dan AIDS di tingkat kelurahan. Seluruh kelurahan di Kota Kupang sudah memperoleh binaan kader WPA (KPA Kota Kupang, 2018). Sejak tahun 2015 Kota Kupang menempati peringkat pertama kasus HIV dan AIDS di Provinsi NTT (Dinkes Provinsi NTT, 2019). Oleh karena itu penelitian ini bertujuan untuk mengetahui bagaimana gambaran sikap, keyakinan, niat dan perilaku warga binaan kader WPA terhadap penanggulangan HIV dan AIDS.

\section{METODE PENELITIAN}

Jenis penelitian ini adalah kuantitatif dengan desain deskriptif (Nazir, 2013). Populasi adalah seluruh warga yang pernah memperoleh pendampingan kader WPA berjumlah 510 orang. Perhitungan besar sampel menggunakan rumus Slovin (Akdon, Riduwan, 2013) dan diperoleh besar sampel sebanyak 102 orang. Teknik pengambilan sampel dilakukan secara random.

Data dikumpulkan dengan menggunakan kuesioner yang terdiri dari variabel pengetahuan, sikap, keyakinan, niat dan perilaku. Data dianalisis dengan distribusi frekuensi dengan mengkategorikan setiap variabel yaitu 'baik' dan 'buruk' (Sugiyono, 2017). Jumlah pertanyaan untuk variabel pengetahuan adalah 10 butir pertanyaan dengan pilihan benar dan salah. Pertanyaan yang diberikan terkait dengan defenisi HIV dan AIDS, penularan, penghapusan stigma dan diskriminasi terhadap ODHA, tes HIV, pencegahan dan pengobatan. Nilai paling rendah untuk variabel pengetahuan adalah 0 dan nilai paling tinggi adalah 10. Variabel sikap, keyakinan dan niat terdiri atas 7 butir pernyataan dengan menggunakan skala Likert yang terdiri dari 5 pilihan jawaban (Azwar, 2015). Pernyataan terdiri atas favorable dan unfavorable. Pada pernyataan favourable untuk pilihan 'Sangat Setuju', 'Setuju', 'Tidak Tahu', 'Tidak Setuju', dan 'Sangat Tidak Setuju' secara berurutan diberi nila 5 sampai 1 . Sedangkan untuk pernyataan unfavourable untuk pilihan 'Sangat Setuju, 'Setuju', 'Tidak Tahu', 'Tidak Setuju', dan 'Sangat Tidak Setuju' secara berurutan diberi nila 1 sampai 5.

Pernyataan yang diberikan terkait dengan upaya penanggulangan HIV dan stigma. Nilai paling rendah adalah 7 dan nilai paling tinggi adalah 35 . Variabel perilaku terdiri dari 7 pernyataan dengan pilihan 'ya' dan 'tidak'. Nilai paling rendah nol dan nilai 
paling tinggi adalah 7. Variabel perilaku menanyakan upaya yang dilakukan untuk pencegahan dan penanggulangan HIV. Skor untuk kategori baik bila nilai yang diperoleh lebih besar atau sama dengan 70 persen. Kategori 'buruk' bila nilai kurang dari 70 persen.

\section{HASIL DAN PEMBAHASAN}

Karakteristik responden yang menjadi binaan kader WPA berdasarkan umur paling banyak pada usia dibawah 45 tahun dengan usia yang rendah 18 tahun. Responden paling banyak tidak bekerja sebanyak 69 (67,6\%) orang, jenis kelamin perempuan sebanyak 60 $(58,8 \%)$ orang dan pendidikan paling banyak tamat SMA sebanyak 92 (90,2\%). Hasil penelitian diperoleh berdasarkan analisis deskriptif kuantitatif. Sebagian besar responden memiliki pengetahuan tentang definisi HIV dan AIDS, stigma dan diskriminasi, penularan, pencegahan dan pengobatan berada pada kategori baik yaitu sebanyak $72(70,6 \%)$. Nilai paling rendah yaitu 2, artinya jawaban responden yang benar sebanyak 2 dari 10 pertanyaan pengetahuan.

Demikian juga untuk variabel sikap sebanyak $59(57,8 \%)$, keyakinan sebanyak 58 $(56,9 \%)$ dan niat sebanyak $56(54,9 \%)$ masingmasing lebih banyak berada dalam kategori baik. Namun bila dibandingkan dengan jumlah responden yang berada dalam kategori buruk selisihnya tidak lebih dari 60 persen. Ini menunjukkan perbedaan jumlah responden yang memiliki nilai baik dan buruk hampir sama banyaknya. Pada variabel perilaku, responden lebih banyak berada pada kategori buruk. Jawaban responden dengan nilai paling rendah yaitu pada variabel perilaku dimana hanya memiliki nilai 1 jawaban yang benar yaitu pencegahan HIV.

Stop pemberian stigma dan diskriminasi terhadap ODHA adalah jawaban yang seluruh responden menjawab pilihan 'ya'.
Perilaku yang paling sedikit dilakukan yaitu tindakan tes HIV. Hampir seluruh responden belum melakukan tes HIV. Alasan yang diberikan karena belum ada waktu untuk pergi ke layanan tes HIV. Selain itu alasan tidak melakukan tes HIV karena responden takut mengetahui hasilnya dan belum siap untuk menyampaikan pada keluarga dan diketahui oleh masyarakat.

Tabel 1. Distribusi karakteristik, pengetahuan, sikap, keyakinan, niat dan perilaku warga binaan kader WPA terhadap penanggulangan HIV dan AIDS.

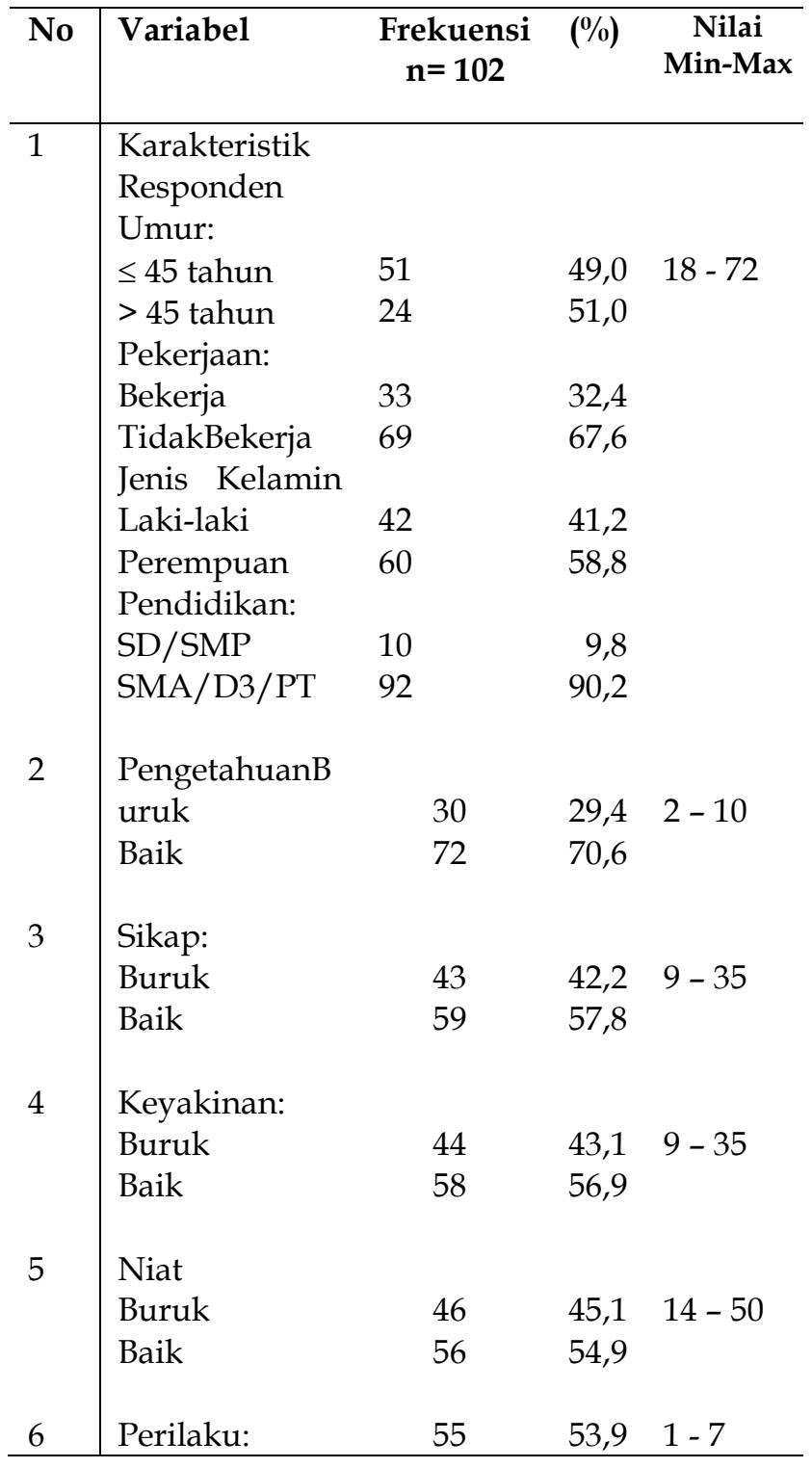


IAKMI Jurnal Kesehatan Masyarakat Indonesia, Volume 1, No. 1, April 2020

Journal Homepage : http://jurnal.iakmi.id/index.php/IJKMI

ISSN 2721-9437 (Media Online)

\begin{tabular}{lll}
$\begin{array}{l}\text { Buruk } \\
\text { Baik }\end{array}$ & 46 & 46,1 \\
\hline
\end{tabular}

Kader WPA di Kota Kupang mulai dibentuk sejak tahun 2013 di 10 Kelurahan, kemudian tahun 2015 kelompok WPA dibentuk di semua Kelurahan yang tersebar pada 6 kecamatan di Kota Kupang. Sejak pembentukannya, kelompok WPA sudah mulai melakukan melakukan penyuluhan HIV dan AIDS, serta mengajak warga untuk ikut dalam mobile Voluntary Conseling and Testing (VCT), dimana VCT ini dilakukan untuk mendeteksi dini HIV dalam tubuh. WPA juga melakukan pemetaan potensi penularan pada setiap kelurahan serta sosialisasi di posyandu.

Hasil penelitian ini menunjukkan bahwa sebagian besar pengetahuan warga binaan kader WPA berada dalam kategori baik. Hampir semua warga mengetahui dengan baik bagaimana penularan dan pecegahan HIV dan AIDS. Penelitian yang dilakukan di Kabupaten Badung terhadap remaja menunjukkan bahwa penyuluhan berpengaruh terhadap perbaikan pengetahuan tentang HIV (Hendra, Hayati \& Maidartati 2017). Pendidikan kesehatan tentang HIV dan AIDS bagi warga diberikan karena angka kejadian HIV dan AIDS sudah menjadi masalah di tingkat keluarga. Sosialisasi yang diberikan kader WPA berupa upaya persuasif atau pembelajaran kepada sasaran untuk melakukan tindakan pencegahan yang didasarkan pada pengetahuan dan kesadaran yang diperoleh setelah mendapatkan sosialisasi dari kader WPA.

WPA adalah suatu upaya pendekatan peer group di masyarakat untuk penanggulagan HIV dan AIDS. Metode peer group dengan menggunakan orang-orang dari kelompok masyarakat dimaksudkan untuk mempermudah penyampaian pesan kepada seluruh warga. Seseorang akan lebih bersedia mendengarkan jika pesan-pesan yang disampaikan oleh orang yang berasal dadri lingkungan dan latar belakang sosial yang sama (Haerana, Salfiantini, \& Ridwan, 2016). Penyampaian informasi dari teman sebaya memudahkan informasi untuk dipahami dan diingat (Salmiah, Tahlil, \& Mudatsir, 2018). Pengetahuan yang baik menjadi pendorong bagi masyarakat binaan kader WPA untuk melakukan upaya pencegahan dan penanggulangan HIV dan AIDS (Ferdian, 2017).

Sosialisasi yang intensif dilakukan oleh kader WPA berkontribusi terhadap pengetahuan warga. Keberadaan WPA di Kota Kupang merupakan suatu bentuk dukungan sosial terhadap warga dalam upaya pencegahan HIV dan AIDS. WPA adalah kelompok masyarakat yang terdiri dari berbagai komponen dalam suatu lingkungan masyarakat baik ditingkat desa, kelurahan atau tingkatan yang sejenis yang ada dalam suatu lingkungan tempat tinggal. Secara kelompok, masyarakat tersebut melakukan kegiatan secara aktif dan tersistem dalam melayani dan mengakses sistem layanan dan rujukan yang berkaitan dengan masalah HIV dan AIDS.

Tugas utama WPA adalah memobilisasi masyarakat untuk ikut serta terlibat secara langsung dalam upaya pencegahan dan penanggulangan HIV dan AIDS. Mobilisasi adalah suatu pendekatan dimana masyarakat memimpin dan menentukan sifat tanggapan mereka terhadap apa yang menjadi perhatian bersama dan dimana para anggota dalam komunitas mengambil tanggung jawab dan aktif serta memiliki pengaruh dalam membentuk rencana dan mengambil tindakan (Mulia, 2018). Warga digerakan oleh kader untuk menambah wawasan dan ikut terlibat dalam kampanye HIV dan AIDS. Selain itu WPA juga menjadi sarana bagi warga untuk menyampaikan aspirasinya kepada pemerintah untuk mendukung mereka dalam melakukan penanggulangan HIV dan AIDS (Herawati, 2017). Sikap terhadap perilaku 
ditentukan oleh keyakinan mengenai konsekuensi dari suatu perilaku. Keyakinan ini dapat memperkuat sikap untuk memiliki perilaku apabila berdasarkan evaluasi yang dilakukan individu, diperoleh data bahwa perilaku itu dapat memberikan keuntungan (Ramadhani, 2011).

Pengetahuan seseorang tentang suatu hal akan mempengaruhi sikapnya terhadap hal tersebut. Sikap positip maupun negatif yang diberikan tergantung dari pemahaman orang tersebut sehingga sikap ini selanjutnya akan mendorongnya melakukan tindakan tertentu pada saat dibutuhkan. Namun bila sikapnya negatif, maka individu tersebut akan menghindari untuk melakukannya (Lestyani, 2015). Azizah (2015) dalam penelitiannya di Kota Bandung menemukan bahwa sikap empati pada WPA dalam mencegah dan menanggulangi HIV dan AIDS adalah sebagai tanggung jawab warga negara yang diwujudnyatakan dalam tindakan helping behavior dan social behavior. Dengan demikian, keberadaan WPA ditengah masyarakat serta dukungan dari para kader WPA adalah dua hal penting dalam upaya penanggulangan HIV dan AIDS berbasis masyarakat di tingkat kelurahan.

Warga yang memiliki sikap dan keyakinan yang baik akan memiliki niat untuk melakukan penanggulannga HIV. Semakin baik sikap seseorang terhadap sesuatu maka akan semakin kuat sikap tersebut diwujudkan dalam bentuk perilaku (Wati, Cahyo, \& Indraswari, 2017).

Penelitian yang dilakukan oleh Rauf, Suryoputro, \& Shaluhiyah, 2018) menemukan bahwa terdapat hubungan antara keyakinan dengan penggunaan kondom untuk pencegahan penularan HIV dan AIDS pada waria pekerja seks di Makasar. Dalam WPA, keyakinan bisa dibentuk berdasarkan informasi yang diterima dari kader. Misalnya keyakinan untuk melakukan VCT karena adanya pengetahuan tambahan yang didapat melalui sosialisasi tentang HIV dan AIDS serta adanya dukungan sarana dan prasarana seperti mobile VCT.

Penelitian di Gresik menunjukkan bahwa Ibu hamil yang memiliki niat yang baik akan memiliki perilaku yang baik untuk melakukan VCT sebagai upaya pencegahan HIV (Ernawati, Suryoputro, \& BM, 2016). Niat adalah keputusan untuk bertindak dengan cara tertentu, atau dorongan untuk melakukan suatu tindakan, baik secara sadar atau tidak. Niat merupakan anteseden dari sebuah perilaku yang nampak. Perilaku yang terbentuk dapat diramalkan melaui niat individu (TPB). Niat untuk untuk melakukan pencegahan HIV dan AIDS adalah karena faktor persepsi kegawatan HIV dan AIDS, faktor rekan pendukung dan status perkawinan telah menikah (Monica, Widjanarko, \& Prabamurti, 2019). Pentingnya pengaruh dukungan sosial terhadap niat warga dalam melakukan pencegahan HIV dan AIDS menjadi suatu tantangan tersendiri pada para kader dalam menjalankan program WPA di Kota Kupang. Keberadaan WPA di Kota Kupang merupakan suatu bentuk dukungan sosial terhadap warga dalam upaya penanggulangan HIV dan AIDS. salah satu bentuk dukungan sosial adalah dukungan informasi yang mencakup pemberian nasehat, petunjuk-petunjuk, saran ataupun umpan balik. Yulfira (2015) mengungkapkan bahwa strategi yang dapat dikembangkan melalui pendekatan sosial budaya adalah peningkatan informasi dan pengetahuan masyarakat tentang HIV dan AIDS secara komprehensif, pemberdayaan masyarakat dan penguatan kelembagaaan, peningkatan akses jangkauan pelayanan dan dukungan penguatan regulasi dalam upaya penanggulangan HIV dan AIDS. Dukungan informasi yang diberikan kader WPA dapat diperoleh misalnya melalui sosialisasi tentang HIV dan AIDS yang diadakan bergiliran di setiap Kelurahan di Kota Kupang.

Perilaku warga binaan kader WPA adalah upaya-upaya yang dilakukan untuk penanggulangan HIV dan AIDS. Indikatornya 
adalah tidak memberikan stigma terhadap ODHA, ikut mensosialisasikan isu HIV dan AIDS, melakukan upaya pencegahan, dan sukarela untuk tes HIV. Pemberian stigma pada ODHA adalah salah satu perilaku yang menghambat kesuksesan penanggulagan HIV dan AIDS. Tindakan yang benar paling banyak dilakukan oleh warga yaitu tidak memberikan stigma pada ODHA. Warga yakin stigma dapat mendorong penundaan perawatan dan pengobatan serta kepatuhan dalam pengobatan HIV pada ODHA. Ini menunjukkan bahwa Kader WPA mampu mengajak dan meyakinkan warga bahwa ODHA layak memiliki kehidupan yang sama dengan masyarakat lainnya. ODHA boleh ikut beribadah bersama dan berpartisipasi dalam kegiatan masyarakat.

Hasil penelitian ini menunjukkan bahwa perilaku warga sebagian besar dalam kategori kurang baik yaitu pada kurangnya kesadaran warga melakukan tes HIV. Penelitian yang dilakukan di Menado menunjukkan bahwa sikap yang baik menjadi faktor bagi wanita pekerja seks untuk melakukan tindakan pencegahan (Hamzah, Asrifuddin, \& Akili, 2018). Alasan individu melakukan tes HIV yaitu akses dan mutu layanan yang diberikan saat melakukan VCT (Susanti \& Sari, 2018). Kemampuan individu untuk menjangkau layanan tes HIV mempengaruhi keputusan untuk melakukan tes. Perilaku pencegahan HIV dan AIDS dapat disimpulkan sebagai reaksi individu yang dipengaruhi oleh faktor internal dan eksternal. Ketakutan akan stigma membuat orang cenderung takut untuk melakukan pemeriksaan HIV atau menunda mengungkapakan status HIVnya (Situmeang, Syarif, \& Mahkota, 2017).

Penelitian yang dilakukan di Kota Semarang menemukan bahwa ada hubungan antara persepsi masyarakat tentang WPA dengan perilaku pencegahan penularan HIV dan AIDS (Ferdian, 2015). Dengan demikian keberadaan WPA di Kota Kupang telah mempengaruhi perilaku warga terutama terkait penanggulangan HIV dan AIDS. Pendampingan sebaya berpengaruh terhadap peningkatan pengetahuan, sikap dan praktik pencegahan HIV dan AIDS (Kalungan, 2015). Dukungan sebaya mempengaruhi peningkatan partisipasi orang dalam mengikuti tes untuk deteksi dini HIV.

Pengaruh dukungan sosial juga terungkap dalam penelitian Pichon (2015) di Mid South USA yaitu para ODHA yang menerima terapi ARV pada Ryan White Program. Penelitian tersebut menemukan bahwa sebagian besar responden mengakui adanya pengaruh dukungan dari lembaga Keagamaan seperti Gereja terhadap ODHA, dan dukungan tersebut mempengaruhi kepatuhan ODHA dalam menjalankan terapi ARV, ODHA juga mengakui jarang mengalami stigma akibat status HIV mereka.

Dukungan sosial yang diberikan terkait pencegahan HIV dan AIDS bisa didapatkan dari orang lain atau komunitas disekitar, baik dari yang sebaya atau tak sebaya, termasuk dari kader WPA. Dukungan yang bisa didapatkan dari kader WPA misalnya dukungan informasi berupa sosialisasi, atau dukungan instrumental berupa layanan tes HIV melalui mobile VCT di Kelurahan masingmasing. Perilaku penanggulangan HIV dan AIDS juga terwujud dengan cara membantu ODHA mencapai kualitas hidup, sesuai dengan keterbatasan yang ada akibat terinfeksi HIV dan AIDS. Misalnya, dengan cara membantu memfasilitasi konseling yang bertujuan untuk memulihkan rasa kepercayaan diri, mempertahankan dan meningkatkan kemauan untuk berobat, serta membantu memaksimalkan aktivitas ODHA dalam aktivitas sehari-hari di masyarakat, dengan bersama-sama masyarakat lainnya membantu menciptakan suatu lingkungan yang bebas stigma dan diskriminasi (Herawati, 2017). Selain itu perilaku yang dilakukan responden yaitu ikut serta 
mengkampenyekan pencegahan HIV dan stop stigma pada ODHA.

\section{KESIMPULAN}

Dari hasil penelitian ini dapat diketahui bahwa sikap, keyakinan dan niat warga binaan kader WPA lebih benyak kategori baik namun bila dibandingkan jumlahnya dengan responden yang bernilai buruk selisihnya tidak terlalu jauh. Untuk itu peran kader WPA perlu ditingkatkan dalam memperbaiki sikap, keyakinan dan niat warga untuk terlibat dalam penanggulangan HIV dan AIDS. Perlu upaya peningkatan kesadaran warga dalam melakukan tes HIV yaitu dengan cara mendekatkan layanan VCT di tengah-tangah warga agar mudah dijangkau. Selain itu perlu peningkatan bimbingan dari kader WPA agar warga tidak takut untuk melakukan tes HIV. Pendekatan yang lebih intensif untuk meyakinkan warga dengan sukarela mau malakukan tes HIV.

\section{UCAPAN TERIMA KASIH}

Penulis menyampaikan limpah terimakasih kepada Komisi Penanggulangan AIDS Provinsi NTT yang telah membantu pelaksanaan penelitian, mulai dari identifikasi WPA sampai pengumpulan data. Ucapan terimakasih juga penulis sampaikan kepada seluruh responden yang telah bersedia untuk menjadi bagian dari subjek penelitian. Secara khusus buat seluruh kader WPA yang telah mendampingi penulis untuk bertemu setiap warga sehingga kehadiran penulis dapat diterima warga dan penelitian ini dapat berjalan dengan lancar. Terimakasih juga penulis sampaikan buat Lurah dan Kepala RT/RW di Kota Kupang yang telah memberikan ijin untuk dilaksankannya penelitian ini.

\section{DAFTAR PUSTAKA}

Akdon, Riduwan. 2013. Rumus dan Data dalam Aplikasi Statistika. Bandung: Alfabeta.

Arisona, W. L., Demartoto, A., \& Murti, B. (2017). Safe Sexual Behaviors for Early Detection and Prevention of HIV/AIDS Transmission among Queers in Tulungagung, East Java, Using Theory of Planned Behavior. Journal of Epidemiology and Public Health, 2(2), 164-173.

Azizah, I. A. (2015). Kajian Tentang Sikap Empati Warga Peduli AIDS Dalam Pencegahan dan Penanggulangan HIV/AIDS Sebagai Warga Negara Yang Baik: Studi Deskriptif di WPA Kelurahan Kebon Pisang Kecamatan Sumur Bandung Kota Bandung (Doctoral dissertation, Universitas Pendidikan Indonesia).

Azwar, s. (2015). Teori dan Pengukuran Sikap Manusia. Pustaka Pelajar: Yogyakarta

Demartoto, A. (2018). Warga Peduli Aids Wujud Peran Serta Masyarakatdalam Penanggulangan HIV/AIDS. Jurnal Analisa Sosiologi, 7(1).

Dinas Kesehatan Provinsi NTT (2019). Profil Kesehatan Provinsi Nusa Tenggara Timur 2018. Kupang: Dinkes Provinsi NTT, (Bab 5)

Ernawati, E., Suryoputro, A., \& Mustofa, S. B. (2016). Niat Ibu Hamil untuk Tes HIV di UPT (Unit Pelayanan Terpadu) Puskesmas Alun-Alun Kabupaten Gresik. Jurnal Promosi Kesehatan Indonesia, 11(1), 38-50.

Ferdian, N. (2017). Hubungan Antara Persepsi Masyarakat Terhadap Program "Warga Peduli AIDS" Dengan Perilaku Pencegahan Penularan HIV/AIDS Di Kelurahan Peterongan, Kota Semarang. Jurnal Kesehatan Masyarakat (eJournal), 3(3), 927-935.

Haerana, B. T., Salfiantini, S., \& Ridwan, M. (2016). Peningkatan Pengetahuan Komprehensif HIV dan AIDS melalui 
Peer Group. Media Kesehatan Masyarakat Indonesia, 11(2), 132-138.

Hamzah, W. O. A. S., Asrifuddin, A., \& Akili, R. H. (2018). Faktor-faktor yang berhubungan dengan tindakan pencegahan hiv/aids pada wanita pekerja seks di kota manado. KESMAS, 7(4).

Hendra, W. G., Hayati, S., \& Maidartati, M. (2017). Pengaruh Penyuluhan Kesehatan Terhadap Pengetahuan Remaja Tentang HIV/AIDS Di Kabupaten Bandung. Jurnal Keperawatan BSI, 5(1).

Herawati, E. (2017). Warga Peduli AIDS': Community Participation in the HIV and AIDS Response in Bandung. Mimbar: Jurnal Sosial dan Pembangunan, 33(2), 317326.

Jambak, N. A. (2018). Faktor-faktor yang Mempengaruhi Perubahan Perilaku Pasien HIV/AIDS. Jurnal Mutiara Ners, 1(1), 1-10.

Kementrian Kesehatan RI. (2019). Profil Kesehatan Indonesia 2018. Jakarta: Kemenkes RI, (Bab 5).

KPA Kota Kupang (2017). Pedoman Warga Peduli AIDS, 2017. Kupang

Lestyani, U., \& Rokhanawati, D. (2015). Hubungan Tingkat Kecemasan dengan Sikap dalam Menghadapi Menarche pada Siswi Kelas $V$ di SD Wilayah Kec. Karangnongko Kab. Sleman(Doctoral dissertation, STIKES'Aisyiyah Yogyakarta).

Manurung, I. F., UW, C., \& Probandari, A. (2016). Effect of Health Literacy to the Empowered Servant of God in Supporting Individuals at Risk of HIV and AIDS to Follow VCT. International Journal of Sciences: Basic and Applied Research, 26(1), 231-236.

Monica, B. R., Widjanarko, B., \& Prabamurti, P. N. (2019). Hubungan Pengetahuan, Norma Subjektif dan Persepsi Kontrol Perilaku dengan Niat Ibu Rumah Tangga Berisiko HIV dalam Mengakses Layanan
VCT. Jurnal Kesehatan Masyarakat (eJournal), 7(4), 496-503.

Mulia, S. N. P. B. (2018). Sosialisasi, Mobilisasi Dan Keterlibatan Kelompok Sasaran Dalam Program Pelayanan Ims Di Puskesmas Kabupaten Sukoharjo. IJMSIndonesian Journal on Medical Science, 5(2).

Nazir, M. (2013) Metode Penelitian. Bogor: Ghalia Indonesia

Pichon, L. C., Rossi, K. R., Ogg, S. A., Krull, L. J., \& Griffin, D. Y. (2015). Social support, stigma and disclosure: Examining the relationship with HIV medication adherence among Ryan White Program clients in the Mid-South USA. International journal of environmental research and public health, 12(6), 7073-7084.

Pusat Data dan Informasi (2018). Situasi Umum HIV/AIDS dan Tes HIV. Jakarta: Pusdatin Kemenkes RI, (4-7).

Ramdhani, N. (2011). Penyusunan alat pengukur berbasis theory of planned behavior. Buletin Psikologi, 19(2).

Salmiah, I., Tahlil, T., \& Mudatsir, M. (2018). Pengaruh Pendidikan Sebaya Terhadap Pengetahuan, Sikap dan Keterampilan Siswi SMA tentang Pemeriksaan Payudara Sendiri (SADARI). Jurnal Ilmu Keperawatan, 6(1), 97-111.

Satar, S., Suryoputro, A., \& Shaluhiyah, Z. (2011) Niat Melakukan Tes HIV Pada Eks Pekerja Migran Indonesia Di Kabupaten Lombok Timur. Jurnal Promosi Kesehatan Indonesia, 6(2), 109-117.

Septyanarindri, S. (2011). Hubungan antara Pengetahuan, Sikap Remaja dan Peran Guru Bimbingan Konseling dengan Upaya Tindakan Preventif HIV/AIDS Pada Remaja.

Situmeang, B., Syarif, S., \& Mahkota, R. (2017). Hubungan Pengetahuan HIV/AIDS dengan Stigma terhadap Orang dengan HIV/AIDS di Kalangan Remaja 15-19 Tahun di Indonesia (Analisis Data SDKI Tahun 2012). Jurnal Epidemiologi Kesehatan Indonesia, 1(2). 
Sugiyono. (2017). Metode Penelitian Kuantitatif, Kualitatif, dan R\&D. Bandung: Alfabeta, $\mathrm{CV}$

Sulaeman, E. S., Murti, B., Setyawan, H., \& Rinawati, S. (2018). Exclusive Breastfeeding Behavior Model in Rural Central Java, Indonesia: The Application of Theory of Planned Behavior. Global Journal of Health Science, 10(10).

Susanti, R., \& Sari, K. (2018). Pelayanan Klinik Voluntary Counseling and Testing (VCT) di Rumah Sakit Umum Daerah Ambarawa Kabupaten Semarang Tahun 2017. Indonesian Journal of Midwifery (IJM), 1(1).

Wati, N. S., Cahyo, K., \& Indraswari, R. (2017). Pengaruh Peran Warga Peduli AIDS Terhadap Perilaku Diskriminatif Pada ODHA. Jurnal Kesehatan Masyarakat (e-Journal), 5(2), 198-204.

Rauf, D. A., Suryoputro, A., \& Shaluhiyah, Z. (2018). Analisis Hubungan Persepsi Manfaat Yang Dirasakan Terhadap Konsistensi Penggunaan Kondom Pada
Waria Pekerja Seks Dalam Pencegahan HIV AIDS di Kota Makassar. Al-sihah: The Public Health Science Journal, 10(2).

UNAIDS. Global factsheets 2018. Available from: https://aidsinfo.unaids.org Accessed 30.01.20

Wati, N. S., Cahyo, K., \& Indraswari, R. (2017). Pengaruh Peran Warga Peduli AIDS Terhadap Perilaku Diskriminatif Pada ODHA. Jurnal Kesehatan Masyarakat (e-Journal), 5(2), 198-204.

Yuliza, W. T., Hardisman, H., \& Nursal, D. G. A. (2019). Analisis Faktor yang Berhubungan dengan Perilaku Pencegahan HIV/AIDS Pada Wanita Pekerja Seksual di Kota Padang. Jurnal Kesehatan Andalas, 8(2), 376-384.

Yulfira Media. (2016). Pengembangan Strategi Dalam Upaya Penanggulangan HIV/AIDS Melalui pendekatan Sosial Budaya. Jurnal Ekologi Kesehatan, 15(1). 